\title{
Poisoning in children 4: Household products, plants, and mushrooms
}

\section{Riordan, G Rylance, K Berry}

Management of children who have ingested bleach, white spirit, turpentine, general household cleaning products, alcohol, rodenticides, petrochemicals, essential oils, vapour treatments, nail care products, and washing powder; and also poisonous plants, berries, or mushrooms

n this, the fourth of a series of articles on the management of poisoning, we deal with poisoning caused by the ingestion of household products.

\section{BLEACH}

Household solutions contain approximately 10\% sodium hypochlorite. They are rarely ingested in significant quantity, as they are extremely unpalatable. Commonly encountered effects include nausea, vomiting, and diarrhoea.

Less than $100 \mathrm{ml}$ of household bleach is unlikely to cause serious problems. Fluids should be encouraged, particularly milk.

Oesophageal damage occurs rarely and is associated with concentrated solutions (industrial bleach may contain up to $50 \%$ sodium hypochlorite) or the ingestion of large volumes. Patients at risk of oesophageal damage require hospital admission and careful attention to fluid and electrolyte balance. Early endoscopic examination with gastric aspiration may be considered. Expert advice should be sought.

\section{TURPENTINE, WHITE SPIRIT, AND} TURPENTINE SUBSTITUTE

Turpentine oil has been largely replaced with white spirit and turpentine substitute.

White spirit and turpentine substitute are of relatively low toxicity when ingested. Gastrointestinal irritation is commonly seen. Central nervous system depression may occur if large quantities are ingested. Their main toxicity relates to the risk of aspiration resulting in a chemical pneumonitis. For this reason gastric decontamination is contraindicated.

All patients should be assessed for signs of respiratory distress. This includes measuring oxygen saturation, recording respiratory rate, and auscultating the chest for additional sounds. The majority of cases are asymptomatic and patients do not necessarily require observation. ${ }^{2}$ Careful administration of oral fluids is required and advice must be given to return if children develop cough or fast, noisy, breathing. Children can develop symptoms up to 24 hours postingestion.

Children with symptoms suggestive of pneumonitis require chest $x$ ray examination and observation in hospital. Supportive treatment and intensive monitoring is indicated. The prophylactic use of antibiotics or steroids is not recommended. Complications such as pulmonary oedema and haemorrhage can occur. Steroids have been used in the management of complications but no clear evidence of benefit exists.

Turpentine is an essential oil and, as such, is far more dangerous whether ingested or inhaled. Hospital admission is mandatory. Turpentine can cause irritation and burning throughout the gastrointestinal tract, metabolic acidosis, hepatic failure, renal damage, and altered level of consciousness. Treatment is on the whole supportive. If a significant quantity of turpentine has been ingested, early consideration may be given to gastric evacuation. This should only be performed under anaesthesia with the airway protected from any risk of aspiration.

\section{GENERAL HOUSEHOLD CLEANING PRODUCTS}

The main products ingested in this group are disinfectants, detergents, toilet blocks, and carpet cleaners.

Disinfectants contain a variety of potentially toxic constituents. However in most household products, these substances are present in very small quantities and severe adverse effects are unusual. Symptoms are usually limited to transient gastrointestinal upset and irritation of the oral mucosa. Oral fluids should be encouraged and asymptomatic children, who have consumed small quantities $(<10 \mathrm{ml})$ of domestic disinfectant, may be discharged.

When large quantities, or concentrated solutions, are consumed, disinfectants can cause corrosive effects, acidosis, central nervous system depression, aspiration pneumonia, and hepatic and renal damage. The greatest risk is from products containing phenol based derivatives (for example, chloroxyenol, active ingredient of Dettol). Specialist advice should be sought.

Detergents fall into three main categories-non-ionic, anionic, and cationic — and most products are labelled as such. Non-ionic and anionic detergents are of low toxicity. Observation is only required if respiratory symptoms, suggestive of foam aspiration, are present. $^{2}$ Cationic detergents, such as benzalkonium chloride and cetrimide, are less frequently encountered in domestic cleaners. They may produce corrosive effects if a concentrated solution is consumed. Oral fluids should be encouraged and asymptomatic children may be discharged after a short period of observation. See above for management of corrosive injury.

Toilet blocks may be of two typescistern or rim blocks. Those designed for use in the cistern are less accessible to children but are more likely to cause adverse effects. They may be acid based and, while systemic toxicity is low, local corrosive damage can be a problem. A short period of observation is advisable and oral fluids should be encouraged. See above for management of corrosive injury. Rim blocks may be detergent based or contain paradichlorobenzene. Toxicity is limited to transient gastrointestinal upset. Oral fluids should be encouraged, but milk should be avoided as it enhances paradichlorobenzene absorption. Toilet water containing dilute amounts of either type of toilet block is not toxic.

\section{ALCOHOL, PERFUMES, AND MOUTHWASH}

Ethanol is encountered in alcoholic drinks, mouthwash, perfumes, and aftershaves. Most serious cases of poisoning involve ingestion of large quantities of products containing a lower concentration of ethanol, for example, drinks or mouthwash, rather than the ingestion of concentrated solutions, which are more irritant.

Ethanol causes central nervous system depression, which can lead to respiratory compromise. Ethanol is metabolised in the liver by alcohol dehydrogenase, using NAD as a cofactor. Competition between ethanol metabolism and other metabolic pathways for available NAD supplies results in acidosis and impaired gluconeogenesis. Impaired gluconeogenesis can cause hypoglycaemia in young or fasted children as a result of depleted glycogen stores.

Ethanol concentration is expressed in volume percent; $1 \mathrm{ml}$ of pure ethanol is 
approximately equal to $0.8 \mathrm{~g}$ of ethanol. The volume of distribution of ethanol is $0.6 \mathrm{l}$ per $\mathrm{kg}$.

Children who have ingested the equivalent of $0.4 \mathrm{ml} / \mathrm{kg}$ pure ethanol should be observed for four hours (an amount expected to produce blood ethanol concentration of $50 \mathrm{mg} / \mathrm{dl}$ ). Ingestion of 1.2 $\mathrm{ml} / \mathrm{kg}$ pure ethanol requires hospital admission and regular blood sugar estimation (an amount expected to produce blood ethanol concentration of $80 \mathrm{mg} /$ dl).

Activated charcoal does not prevent absorption and is not indicated. Because of the rapid absorption of ethanol from the stomach and mucus membranes, attempts at inducing emesis or performing gastric lavage are likely to be ineffective.

Blood ethanol concentration can be measured and samples should be taken at least one hour following ingestion. However, measurement is not essential as treatment is supportive and determined on clinical grounds.

Dehydration should be corrected with intravenous fluids-care must be taken as cerebral oedema can occur. Hypoglycaemia should be corrected with 10\% dextrose ( $5 \mathrm{ml} / \mathrm{kg}$ body weight).

A variety of specific therapies have been used, predominantly in adult patients, to attempt to reduce the need for, and duration of, intensive therapy in ethanol poisoning. Flumazenil ${ }^{3}$ and naloxone $e^{4}$ have been used to antagonise the depressant effects of ethanol in overdose; infusion of intravenous fructose, which increases NAD availability, has been used to enhance ethanol metabolism; and haemodialysis has been used to treat patients with a high blood alcohol level $(>300 \mathrm{mg} / \mathrm{dl}){ }^{5}$ The effects of these techniques are not of sufficient clinical benefit to justify their routine use.

\section{RAT AND MOUSE POISONS}

Wide varieties of domestic rodenticides are available, and accurate identification of their constituents is often difficult because of the circumstances in which accidental ingestions occur. Most products are based on warfarin, long acting anticoagulants, or alphachloralose, a chloral derivative.

Anticoagulant based baits cause no immediate effects and urgent medical assessment is not necessary. Prothrombin time should be measured at 24 and 48 hours if more than $0.5 \mathrm{mg} / \mathrm{kg}$ of warfarin, or $0.01 \mathrm{mg} / \mathrm{kg}$ of any other anticoagulant, has been consumed. ${ }^{2}$

Alphachloralose causes central nervous system depression. ${ }^{6}$ Activated charcoal should be given if more than $2 \mathrm{~g}$ (two tablespoons) of wheat pellet product has been ingested. Asymptomatic children should be observed for four hours.
Children ingesting a unidentifiable, wheat based, domestic poison should be treated as if they had consumed a mixture of both poisons. That is, activated charcoal should be administered if more than two tablespoons of product have been ingested, children should be observed for four hours, and all children should have prothrombin time measured at 24 and 48 hours.

Liquid preparations and products set by professional exterminators in agricultural or industrial settings may have different, and potentially far more toxic, constituents. In such circumstances, product identification is essential and specific expert advice is necessary.

\section{PETROCHEMICALS AND ESSENTIAL OILS}

Petrochemicals, such as paraffin, kerosene, petrol, diesel, lubricating, and engine oils, are of low systemic toxicity. The main hazard of accidental ingestion is that of chemical pneumonitis caused by aspiration. This can occur in the absence of vomiting or impaired consciousness.

Essential oils are derived from plants. They are volatile mixtures of esters, alcohols, aldehydes, and ketones. They are used in perfumery, aromatherapy, massage, and as alternative remedies. Turpentine is also an essential oil.

Essential oils are potentially very toxic. Initial effects include mucosal irritation, vomiting, epigastric pain, and diarrhoea. Convulsions, central nervous system depression, and hepatic and renal failure may follow.

Asymptomatic children require six hours observation. Fluids should be encouraged. Symptomatic children require hospital admission. Treatment is supportive. Blood glucose should be monitored. Signs of respiratory distress may indicate oil aspiration.

\section{VAPOUR TREATMENTS}

Decongestant capsules make up the largest group of these treatments accidentally consumed by children. Capsules contain a mixture of essential oils. Ingestion results in oropharyngeal irritation, nausea, vomiting, and diarrhoea. Systemic effects, including central nervous system depression, can occur. If instilled nasally, severe respiratory distress can occur, and respiratory arrest has been reported. ${ }^{?}$

Asymptomatic children should be observed for four hours. Oral fluids should be encouraged. Treatment is symptomatic. These substances can cause corneal ulceration.

Vapour rubs have similar constituents held in a thick ointment base. Symptoms, other than transient gastrointestinal irritation, are unusual. No specific treatment is required.

\section{NAIL CARE}

Nail varnish removers usually contain acetone or ethyl acetate. Other solvents can be used and clear identification is important.

Acetone is rapidly absorbed from the stomach and mucous membranes. It causes local irritation, vomiting, and central nervous system depression. Acetone may produce ketosis, acidosis, and hyperglycaemia.

Children who have ingested more than the equivalent of $2 \mathrm{ml}$ of pure acetone require observation for two hours. Asymptomatic children can then be discharged. Activated charcoal does not bind acetone.

Symptomatic patients require hospital admission. Blood sugar should be monitored and hyperglycaemia corrected if necessary with insulin. Ventilation may be required if consciousness is significantly impaired. Renal function should be monitored carefully as renal tubular damage can occur.

Ethyl acetate also causes mucosal irritation, but large quantities are required to produce central nervous system depression. Asymptomatic children can be discharged after two hours observation. Treatment is supportive.

Nail varnish contains a variety of potentially toxic ingredients. However, the volumes available to children for accidental ingestion are usually small. No action is necessary if no more than one bottle has been consumed. Oral fluids should be encouraged and transient gastrointestinal upset expected.

If more than one bottle has been ingested, expert advice is required.

\section{WASHING POWDER}

Washing powders contain mixtures of enzymes, perfumes, softeners, and anionic and non-ionic detergents. They are of low toxicity and specific treatment is not required.

Dishwasher powders, liquids, and tablets are strongly alkaline. Accidental ingestion can produce severe corrosive injury, although this is usually confined to the oral mucosa, lips, and tongue. At presentation any remaining product should be washed from the skin and oral mucosa. Oral fluids should be encouraged. Attempts at neutralisation are dangerous. Further treatment, where required, is supportive. Asymptomatic children can be discharged. Oesophageal damage can occur in the absence of oral burns and parents should be advised accordingly. Follow up is recommended. ${ }^{8}$

Dishwasher rinse aid contains detergents only and is of low toxicity.

\section{PLANTS AND BERRIES}

Table 1 outlines poison management for the 10 commonest toxic plants ingested by children. 
Table 1 Commonly ingested plants with significant toxic potential

\begin{tabular}{|c|c|c|c|}
\hline Plant & Poisonous parts & Symptoms & Management \\
\hline Laburnum & $\begin{array}{l}\text { All parts } \\
\text { Seed ingestion is the } \\
\text { commonest presentation }\end{array}$ & $\begin{array}{l}\text { Vomiting } \\
\text { Pallor } \\
\text { Dilated pupils } \\
\text { Tachycardia } \\
\text { Dizziness }\end{array}$ & $\begin{array}{l}\text { Activated charcoal if more than } 5 \text { seeds ingested }{ }^{2} \\
\text { Observation }\end{array}$ \\
\hline $\begin{array}{l}\text { Deadly Nightshade (Atropa } \\
\text { belladona) }\end{array}$ & $\begin{array}{l}\text { All parts poisonous but } \\
\text { berry ingestion is the } \\
\text { commonest presentation }\end{array}$ & $\begin{array}{l}\text { Dry mouth } \\
\text { Dilated pupils } \\
\text { Hallucinations } \\
\text { Urinary retention } \\
\text { Agitation } \\
\text { Ataxia } \\
\text { Muscle in-coordination } \\
\text { Convulsions } \\
\text { Coma }\end{array}$ & $\begin{array}{l}\text { Activated charcoal if any plant material has been } \\
\text { ingested. Additional methods of gastric } \\
\text { decontamination if }>5 \text { berries ingested-intestinal } \\
\text { motility may be impaired and absorption prolonged } \\
\text { Treatment is supportive. Physostigmine should be } \\
\text { reserved for cases where life threatening symptoms fail } \\
\text { to respond to adequate supportive measures } \\
\text { Symptoms can be delayed for up to } 12 \text { hours following } \\
\text { ingestion and hospital admission is mandatory }\end{array}$ \\
\hline Laurel (Prunus laurocerasus) & $\begin{array}{l}\text { Leaves and broken seeds of } \\
\text { the fruit are the most } \\
\text { poisonous parts }\end{array}$ & $\begin{array}{l}\text { Gastrointestinal upset } \\
\text { Salivation } \\
\text { Flushing } \\
\text { Convulsions } \\
\text { Coma } \\
\text { Arrhythmias }\end{array}$ & $\begin{array}{l}\text { If only the pulp of the berry eaten, or stones swallowed } \\
\text { whole, no treatment is required. Activated charcoal for } \\
\text { leaves or broken seeds } \\
\text { Symptoms can be delayed for up to } 4 \text { hours }\end{array}$ \\
\hline Lupin & & & Only toxic in large quantities. Activated charcoal \\
\hline Yew trees & $\begin{array}{l}\text { All parts of the tree are } \\
\text { toxic except the pulp of the } \\
\text { berry }\end{array}$ & $\begin{array}{l}\text { Nausea } \\
\text { Vomiting } \\
\text { Anticholinergic effects } \\
\text { Drowsiness } \\
\text { Bradycardia } \\
\text { Arrhythmia } \\
\text { Convulsions }\end{array}$ & $\begin{array}{l}\text { Asymptomatic children should be observed for } 4 \text { hours } \\
\text { Gastric decontamination does not seem to influence } \\
\text { outcome }^{9} \\
\text { Treatment is supportive } \\
\text { Serious cases are very rare }\end{array}$ \\
\hline $\begin{array}{l}\text { Woody nightshade } \\
\text { (Solanum dulcamara) } \\
\text { "Bittersweet" }\end{array}$ & $\begin{array}{l}\text { All parts of the plant are } \\
\text { toxic, unripe fruits } \\
\text { particularly so }\end{array}$ & $\begin{array}{l}\text { Drowsiness } \\
\text { Ataxia } \\
\text { Nausea } \\
\text { Vomiting } \\
\text { Oropharyngeal irritation }\end{array}$ & $\begin{array}{l}\text { Activated charcoal if }>5 \text { ripe berries, or any unripe } \\
\text { berry, have been consumed } d^{2}>\text { Asymptomatic patients } \\
\text { should be observed for } 8 \text { hours } \\
\text { Treatment is supportive }\end{array}$ \\
\hline $\begin{array}{l}\text { Cuckoo Pint (Arnum } \\
\text { maculatum) }\end{array}$ & & $\begin{array}{l}\text { Mucosal irritation, oedema, and } \\
\text { occasionally ulceration } \\
\text { Local skin irritation and blistering }\end{array}$ & $\begin{array}{l}\text { Treatment is symptomatic } \\
\text { Analgesia and antihistamines } \\
\text { Effects appear rapidly and observation of asymptomatic } \\
\text { children is unnecessary }\end{array}$ \\
\hline Elder (Sambucus nigra) & $\begin{array}{l}\text { All parts of the plant are } \\
\text { mildly toxic, unripe berries } \\
\text { particularly so }\end{array}$ & $\begin{array}{l}\text { Nausea } \\
\text { Vomiting } \\
\text { Dizziness } \\
\text { Tachycardia } \\
\text { Convulsions }^{10}\end{array}$ & $\begin{array}{l}\text { Consider gastric decontamination if }>10 \text { berries } \\
\text { consumed } \\
\text { Treatment is symptomatic }\end{array}$ \\
\hline Mistletoe ${ }^{10}$ & $\begin{array}{l}\text { All parts of the plant are } \\
\text { toxic except the flesh of the } \\
\text { berry }\end{array}$ & $\begin{array}{l}\text { Nausea } \\
\text { Vomiting } \\
\text { Diarrhoea } \\
\text { Muscle weakness } \\
\text { Pupil dilatation } \\
\text { Diuresis } \\
\text { Bradycardia can occur }\end{array}$ & $\begin{array}{l}\text { Symptoms are unlikely if less than } 3 \text { berries are } \\
\text { consumed } \\
\text { Treatment is symptomatic. Atropine for bradycardia } \\
\text { Effects can last for several days }\end{array}$ \\
\hline $\begin{array}{l}\text { Rhubarb" } \\
\text { The leaves contain oxalates } \\
\text { and are toxic }\end{array}$ & $\begin{array}{l}\text { Symptoms of gastric } \\
\text { irritation predominate } \\
\text { Oxalates chelate calcium } \\
\text { and hypocalcaemia can } \\
\text { complicate ingestion }\end{array}$ & $\begin{array}{l}\text { Milk may help to neutralise oxalic acid } \\
\text { Treatment is otherwise supportive }\end{array}$ & \\
\hline
\end{tabular}

\section{MUSHROOMS}

While specific advice regarding the accidental ingestion of fungi is difficult, because of the diversity of the kingdom, a number of general points can be made.

Serious cases of poisoning are very rare. Symptoms occurring within six hours of ingestion are unlikely to be a result of consumption of the most poisonous species. Mushrooms growing in lawns are unlikely to be seriously toxic; the most poisonous mushrooms are largely confined to woodland areas.
Mushrooms with very pale, or white gills (responsible for the spoke pattern on the underside of the cap), should be regarded with particular suspicion.

Amanita palloides, the Death Cap, is the most deadly fungus known and is responsible for the majority of deaths from mushroom poisoning. ${ }^{12}$ Poisoning is characterised by a delay of between 6 and 24 hours in the onset of symptoms following ingestion. Violent vomiting, diarrhoea, and abdominal pain are the first symptoms. Patients then make an apparent recovery, but this is followed a few days later by hepatic and renal failure, leading to death. The main toxins responsible are the amatoxins. They inhibit nuclear RNA polymerase B, interrupting protein synthesis. Amatoxins are excreted in urine and bile. They undergo extensive enterohepatic circulation.

Early recognition of Amanita poisoning is important. Treatment includes gastric lavage, repeated doses of activated charcoal, and continuous duodenal aspiration. A number of drugs have been 


\begin{tabular}{l} 
Table 2 Products of low toxicity \\
\hline Air freshener \\
Baby oil \\
Bath oil \\
Conditioner \\
Deodorant \\
Emulsion paint \\
Flourescent necklaces etc \\
Glue (PVA and Superglue) \\
Hair treatments \\
Make up and skin care \\
Plant care \\
Polish \\
Silica gel \\
Soap \\
Thermometer \\
Washing up liquid
\end{tabular}

Note: Some of the products listed present a significant choking hazard that should not be overlooked.

advocated for the management of amatoxin poisoning. ${ }^{13}$ High dose benzylpenicillin is probably the most effective, possibly acting by inhibiting hepatocyte toxin uptake or displacing protein bound toxin. Other possible treatments include the use of forced diuresis ${ }^{14}$ or resin haemoperfusion. ${ }^{15}$

\section{INGESTIONS OF LOW TOXICITY}

A wide range of household products are accidentally ingested by children. Many are of very low toxicity (see table 2 ).

\section{SEEKING FURTHER ADVICE}

Specific, expert advice on all aspects of poisoning is available to medical professionals in the United Kingdom via the National Poisons Information Service (NPIS). The regional centres that make up this service have recently introduced a single national enquiry number: 08706006266 .

A wide range of easily accessible and highly practical advice is available through the NPIS website. ${ }^{16}$ This free service is restricted to medical professionals. On line registration is available at http://www.spib.axl.co.uk/toxbase/.

\section{Arch Dis Child 2002;87:403-406}

\section{Authors' affiliations}

M F Riordan, Department of Pediatrics, Yale University Medical School, USA

G W Rylance, Department of General

Paediatrics, Royal Victoria Infirmary, Newcastle upon Tyne, UK

K Berry, Accident and Emergency Department Birmingham Children's Hospital, Birmingham, UK

Correspondence to: Dr K Berry, Accident and Emergency Department, Birmingham Children's Hospital, Steelhouse Lane, Birmingham B4 6NH UK; kathleen.berry@bhamchildrens.wmids.nhs.uk

\section{REFERENCES}

1 Cardona J, Boussemart T, Berthier $M$, et al. [Accidental bleach ingestion in children: results of a survey in 11 anti-poison centres. Proposals for management]. Pediatrie 1993;48:705-9.
2 Bates N, Edwards N, Roper J, et al. Paediatric toxicology: handbook of poisoning in children. London: Macmillan Reference Limited, 1997.

3 Lister RG, Nutt D. Is Ro 15-4513 a specific alcohol antagonist? Trends Neurosci $1987 ;(6): 223-5$.

4 Matilla MJ, Nuotto E, Seppala T. Naloxone is not an effective antagonist of ethanol. Lancet $1981 ; 1: 775-6$.

5 Lasker N. Use of hemodialysis and forced diuresis in the treatment of poisoning. Ann Clin Lab Sci 1976:6:377-80.

6 Thomas HM, Simpson D, Prescott LF. The toxic effects of alpha-chloralose. Hum Toxicol 1988;7:285-7.

7 Wyllie JP, Alexander FW. Nasal instillation of "Olbas Oil" in an infant [letter]. Arch Dis Child 1994;70:357-8.

8 Nuutinen $M$, Uhari $M$, Karvali $T$, et al. Consequences of caustic ingestions in children. Acta Paediatr 1994;83:1200-5

9 Krenzelok EP, Jacobsen TD, Aronis J. Is the yew really poisonous to you? J Toxicol Clin Toxicol 1998;36:219-23.

10 Lang DC. The complete book of British berries. London: Threshold Books Ltd, 1987.

11 Sanz P, Reig R. Clinical and pathological findings in fatal plant oxalosis. Am J Forensic Med Pathol 1992;13:342-5.

12 Death-cap poisoning. Lancet 1972;1:1320-1.

13 Floersheim GL. Antidotes to experimental-amanitin poisoning. Nat $\mathrm{New}$ Biol 1972;236: 115-17.

14 Vesconi S, Langer $M$, lapichino $G$, et al. Therapy of cytotoxic mushroom intoxication. Crit Care Med 1985;13:402-6.

15 Mydlik M, Derzsiova K, Mizla P, et al. [Hemoperfusion in mushroom poisoning. Clinical analysis of 58 patients]. Cas Lek Cesk 1993;132:464-7.

16 Good AM, Bateman DN. TOXBASE on the Internet. J Accid Emerg Med 1999; 16:399. 